\title{
$\underline{\mathbf{P}-115}$
}

\section{Theoretical Studies on the Physical Properties of 2,6-ditert-Butyl Phenol Derivatives as a Chain-Breaking Radical Scavenger}

\author{
Ku Halim Ku Bulat*, Isrina Mohamad Saleh, Siti Balqis Che Othman, Radiah Ali and Juriffah \\ Ariffin
}

Department of Chemical Sciences, Faculty of Sciences and Technology, Universiti Malaysia Terengganu, 21030, Kuala Terengganu, Terengganu Darul Iman, Malaysia; E-mail: keriang@umt.edu.my

The aim of this research project is to study the effect of para-substituents on the physical properties of 2,6-ditert-butyl phenol derivatives as a vegetable oil chain-breaking radical scavenger. In this theoretical studies, Gaussian 09 quantum mechanical software package at the theoretical level of DFT B3LYP/6-31G(d,p) were employed to evaluate the optimized geometry at the local minimum of total potential energy structures. The physical parameters such as the total electronic energy, the strength and the length of hydrogen bonding, the $\mathrm{O}-\mathrm{H}$ antioxidants parameters(bond length, bond strength, Wiberg bond index), and the dipole moment of the molecules involved were assessed at the same theoretical level by using Natural Bond Orbital method. The para-substituents in consideration were $-\mathrm{H},-\mathrm{CH}_{3},-\mathrm{OH},-\mathrm{OCH}_{3}$ and propyl ester $\left(\mathrm{COOCH}_{2} \mathrm{CH}_{2} \mathrm{CH}_{3}\right)$. $\mathrm{Results}$ showed that hydroxyl $(-\mathrm{OH})$ para derivative formed the strongest transition-state complex $(24.5 \mathrm{~kJ} / \mathrm{mol})$ with $\mathrm{C} 9$-hydroperoxyl radical of methyl linoleate followed by $-\mathrm{OCH}_{3}(23.7 \mathrm{~kJ} / \mathrm{mol}),-\mathrm{CH}_{3}(21.8 \mathrm{~kJ} / \mathrm{mol}),-\mathrm{H}(21.4 \mathrm{~kJ} / \mathrm{mol})$, and $-\mathrm{COOCH}_{2} \mathrm{CH}_{2} \mathrm{CH}_{3}(20.7$ $\mathrm{kJ} / \mathrm{mol})$. However, the para-derivative of propyl ester $\left(-\mathrm{COOCH}_{2} \mathrm{CH}_{2} \mathrm{CH}_{3}\right)$ has the lowest Wiberg bond index of O-H bond (0.653) compared to the other derivatives of the 2,6-ditert-butyl phenol $\left[-\mathrm{H}(0.661),-\mathrm{CH}_{3}(0.663),-\mathrm{OCH}(0.664),-\mathrm{OH}\right.$ $(0.665)]$. This means that the derivatives with hydroxyl or propyl ester group at para-position should be more effective as an antioxidant for high-linoleic vegetable oil rather than the available commercial BHT where the substituent is methyl group.

Keywords: 2,6-ditert-butyl phenol, methyl linoleate, chain-breaking radical scavenger, Natural Bond Orbital, Wiberg bond index. 